\title{
Exclusion of oesophageal atresia by passage of a nasogastric tube: an exception to the rule
}

\author{
Ramnik V Patel, ${ }_{1}^{1}$ Paul B Jackson, ${ }^{2}$ Paolo De Coppi, ${ }^{2}$ Agostino Pierro ${ }^{2}$
}

${ }^{1}$ Department of Paediatric Urology, University College London Hospitals NHS Foundation Trust, London, UK ${ }^{2}$ Department of Paediatric Surgery, GOSH and ICH, London, UK

\section{Correspondence to} Ramnik V Patel, ramnik@doctors.org.uk

\section{DESCRIPTION}

A term baby girl had an absent anus at birth. A nasogastric tube (NGT) was passed and bile aspirated. A babygram confirmed it in the stomach with a double bubble appearance and a contrast study through the NGT showed an obstruction consistent with midgut malrotation and/or duodenal atresia (figure 1). Laparotomy, colostomy, Ladd's procedure and duodenoduodenostomy were performed. At the end of the procedure the NGT was dislodged and could not be replaced. A bronchoscopy and an oesophagoscopy confirmed an oesophageal atresia (OA) and distal tracheo-oesophageal fistula (TOF). Surgical repair of the OA/TOF was performed. It is accepted that the diagnosis of $\mathrm{OA}$ is confirmed by passing a firm NGT through the mouth into the oesophagus to the point at which resistance is met. ${ }^{1}$ Our case is a living testimony of an exception to this established rule. Even in the present era of prenatal diagnosis, the sensitivity and specificity of OA being diagnosed is very low. Multiple atresias of the gut or VACTREL association require one to rule out TOF/ OA. Moreover, in the alimentary tract a proximal obstruction is dealt with first and correction proceeds distally. The plausible explanation for the mechanism how the NGT could reach the stomach even in the presence of complete obstruction in the proximal oesophagus includes the passage of the NGT straight into the trachea followed by passage into the fistula and the stomach or it can pass through the proximal pouch fistula into the trachea and through the distal fistula back into the lower oesophagus and stomach. ${ }^{2-3}$

\section{Learning points}

- The cardinal rule: the pathognomonic feature of an oesophageal atresia is the inability to pass a nasogastric tube (NGT) into the stomach.

- The passage of an NGT does not always exclude the presence of an oesophageal atresia.There are some exceptions to the rule and these can delay its detection.

- In a case of anorectal malformation with duodenal atresia, a high index of suspicion for oesophageal atresia should be kept in mind and when interpreting the $\mathrm{X}$-rays, the widest possible differential diagnosis should always be entertained-what we do not look for we would not see.
To cite: Patel RV, Jackson PB, De Coppi P, et al. BMJ Case Rep Published online: [please include Day Month Year] doi:10.1136/bcr-2013 201175
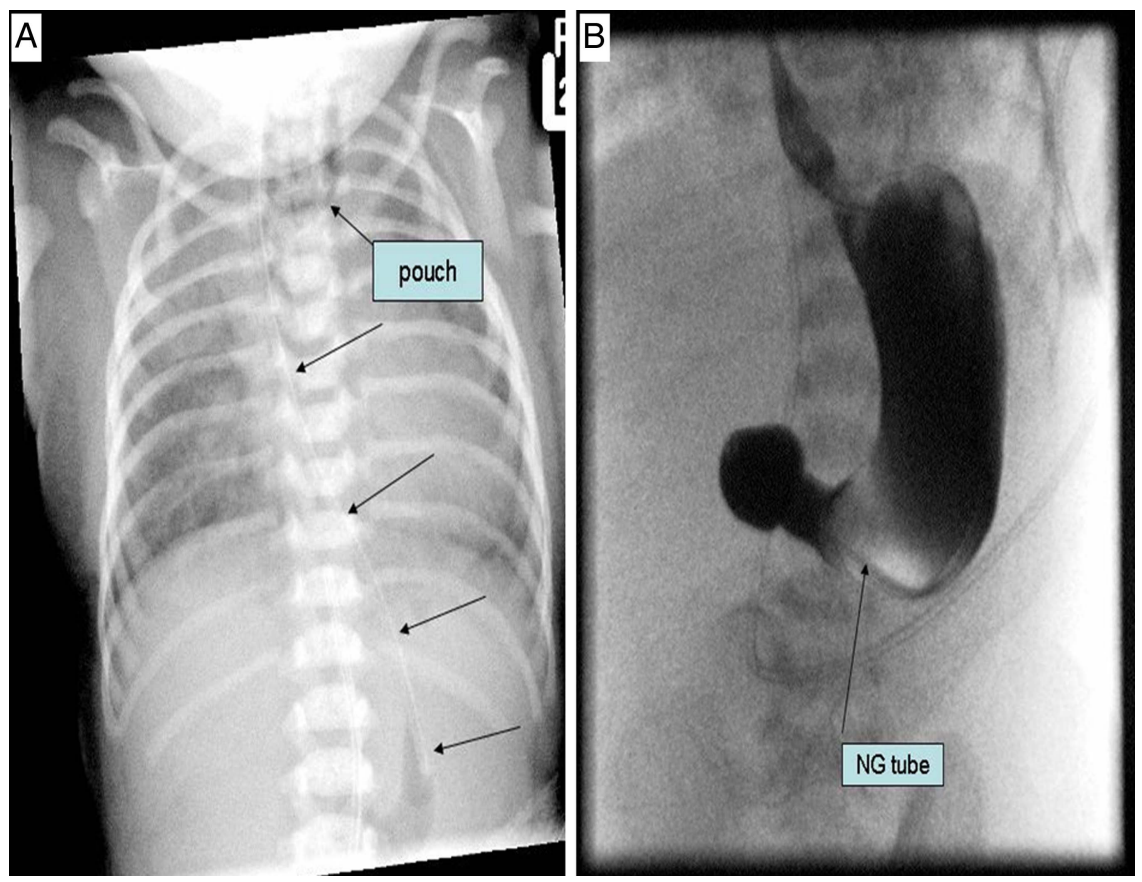

Figure 1 (A) Babygram showing nasogastric tube in the stomach-note outline of the proximal pouch in the neck 9 top arrow) and the course of the NGT in the chest (middle arrows) and the tip in the stomach (bottom arrow) and double bubble appearance of gas. (B) Upper gastrointestinal contrast with the tip of nasogastric tube in the pyloric area and complete duodenal obstruction. 
Contributors All the authors have made substantial contributions to the conception and design of the paper, search of the literature, the acquisition, analysis and interpretation of the data, to draft the article or revising it critically for important intellectual content and to the final approval of the version to be published.

Competing interests None.

Patient consent Obtained.

Provenance and peer review Not commissioned; externally peer reviewed.

\section{REFERENCES}

1 Soccorso G, England RJ, Godbole PP, et al. Mind the gap: delayed diagnosis of oesophageal atresia and tracheo-oesophageal fistula due to passage of a nasogastric tube. Arch Dis Child Fetal Neonatal Ed 2012;97:F463-4.

2 Alexander A, Millar AJ. The passage of a nasogastric tube does not always exclude an oesophageal atresia. Afr J Paediatr Surg 2009;6:47-8.

3 Celayir AC, Erdogan E. An infrequent cause of misdiagnosis in oesophageal atresia. J Pediatr Surg 2003;38:1389.

Copyright 2013 BMJ Publishing Group. All rights reserved. For permission to reuse any of this content visit http://group.bmj.com/group/rights-licensing/permissions.

BMJ Case Report Fellows may re-use this article for personal use and teaching without any further permission.

Become a Fellow of BMJ Case Reports today and you can:

- Submit as many cases as you like

- Enjoy fast sympathetic peer review and rapid publication of accepted articles

- Access all the published articles

- Re-use any of the published material for personal use and teaching without further permission

For information on Institutional Fellowships contact consortiasales@bmjgroup.com

Visit casereports.bmj.com for more articles like this and to become a Fellow 